\title{
Unbehagen and the subject: An interview with Slavoj Žižek
}

\author{
Slavoj Žižek ${ }^{\mathrm{a}}$, Maria Aristodemou ${ }^{\mathrm{b}}$, Stephen Frosh ${ }^{\mathrm{c}}$ and \\ Derek Hook ${ }^{\mathrm{d}, *}$ \\ ${ }^{a}$ The Birkbeck Institute for the Humanities, Birkbeck, University of London, \\ Malet Street, London WC1E7HX, UK.

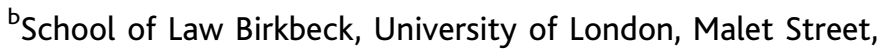 \\ London WC1E7HX, UK. \\ 'Department of Psychosocial Studies, Birkbeck College, Malet Street, \\ London WC1E7HX, UK. \\ dSocial Psychology, London School of Economics, Houghton Street, \\ WC2A 2AE, London, UK. \\ *Corresponding author.
}

\begin{abstract}
This article is an edited transcript of an interview with Slavoj Žižek conducted by Stephen Frosh and Maria Aristodemou at the Birkbeck Institute for the Humanities on the 18 June 2008. The focus of the interview was Slavoj Žižek's engagement with psychoanalysis.

Psychoanalysis, Culture \& Society (2010) 15, 418-428. doi:10.1057/pcs.2010.22
\end{abstract}

Keywords: Lacanian subject; primordial father; paternal authority; Unbehagen in der Kultur

Stephen Frosh: The focus of today's conversation is psychoanalysis. Slavoj's encounter with psychoanalysis has been far ranging since the beginning of his writing. It has encouraged a burgeoning interest in the application of Lacanian thinking to the political and cultural spheres. One of the things we might talk about later on is the effect of the 'Žižekification' of Lacan, that is, the issue of reading Lacan outside of $\check{Z}$ ižek. 
Slavoj Žižek: Let me be critical towards Lacan. When you told me earlier that not only am I focusing too much on Lacan within the broader realm of psychoanalysis and that I exert too much influence in that people read Lacan through my, probably narrow, perspective, it is true. But there is at least one thing that I always try to do, to render palpable the openness - not in any positive nondogmatic sense - to put it in very simple terms, to show how Lacan is totally unsure and, in an ironic way, cheats, changes his position radically. For example, I discovered a new excellent source to Lacan, Francois Balmes's What Lacan Says about Being. It is a wonderful analysis of how, when Lacan refers to the topic of being, basically to Heidegger, he radically changes his position. It proves how, in the 1950s, Lacan was flirting with Heidegger's critique of subjectivity. Then, at a certain point, in the early 1970s, Lacan made the choice for Descartes against Heidegger and triumphantly returned to the cogito. He offers a nice reading of how Lacan played all possible variations. He started with this standard rereading of Descartes: 'I am not where I think'. Then what he did in Seminar XI (The Four Fundamentals of Psychoanalysis), already more intelligent, he turns it around. The site of truth is not being but thought: 'I do not think where I am'. The unconscious is the thought without being, not being itself. Then in his final position in the '66-67 Seminar on the Logic of Fantasy, unfortunately not yet published, he returns to the cogito as unity of being and thought, but the idea - a very nice one - is that it is neither being nor thought. It is that the Cartesian cogito, this cogito ergo sum, is reduced to pure thought, which is void, nonthought - just I think I am nothing, no content, and at the same time the being of cogito is void.

Lacan, of course, agrees with Heidegger that language is the house of being, but, you know, Fred Jameson's book The Prison-House of Language for Lacan should be Torture-House of Language. That is to say, Heidegger still has this trust, not passivity, 'Open yourself to language', 'Language speaks through you'. But Lacan's idea is that, at the most elementary, when language speaks to you, you are tortured; there is radical discordance. That's the beauty of Lacan. This is why Lacan keeps the term 'subject'. Subject is for Lacan precisely that ' $\mathrm{x}$ ' which is the outcome of this torture.

This idea came to me. I started to appreciate the writer Elfriede Jelinek. She had a wonderful, very Lacanian, phrase: we must torture language to make it tell the truth. That is the big topic of her work, language as torturing. Hegel has a wonderful passage in his Philosophy of History where he says that Thucydides' History of the Peloponnesian War is the 'game for humanity of the real war'. This is a totally crazy Hegelian idealist idea: that thousands had to die, a war was fought, so a guy could write a book. I am tempted, in the same tasteless way, to say that things like Josef Fritzl have to happen, so that Jelinek can write. 


\section{Père-version}

SŽ: Here we can see how Freud was not an idiot. Freud's idea of the primordial father is, of course, a stupidity if you read it as a literal anthropological hypothesis but not if you read it as a fantasmatic feature that has what Freud called 'psychological reality'. We have a symbolic father, that is, an authority, and a castrated father, but these always have to be accompanied by this primordial aspect, which can act in different versions. It can be a fantasy that determines your dreams. Do you know Freud's dream of Irma's injection? Beneath it is this fantasy. Freud hints somewhere that the fantasy is that Irma and the other three women are all basically his daughters, that 'I will have them'. This is one proof that Freud really knew what he was doing. Isn't this a wonderful example of how Lacan was right when he used the term 'père-version', perversion as father's version? We should be very precise here. Did you notice how sociologists, to get rid of this trauma - 'How could this Fritzl happen?' - tried to relativize it by saying that it must have something to do with Austrian oppression, Austrian Nazism.

No, it is too easy to relativize it in this way. There is something in the very identity of being a father that points in this direction. I remember once when my father was still alive I talked about changing my name. My father exploded and started to shout at me, 'What are you saying? Don't you know that by giving you my name I have given you everything? Don't you know that you owe everything to me?' This idea, that he totally owns me ... I was shocked how, in a respectable, normal father, this dimension exploded.

If we are looking for the Austrian feature of this Fritzl, we should look elsewhere. Did you see one of the greatest films of all time, The Sound of Music? They are one happy family. If you look at it, that fantasy, Fritzl is von Trapp realized. It is the same dream, another psychotic element.

Maria Aristodemou: It is the same in Psycho, with the primordial id in the basement.

SŽ: In Austria they published a text of mine on the Fritzl case, but they changed the title. My title was The Basements are Alive with the Sound of Music. At this level, we can see where psychoanalysis is of use today. For me, the Fritzl case is a clear example of how Freudian categories are operative in notions like the primordial father, like two levels of paternal authority. The way I read the Fritzl arrangement is architecturally; it is a kind of pure realization, the normal, the ideal of the family and then the basement, the ...

MA: The id.

SŽ: It is literally realized. What interests me is how another Fritzl, the Fritzl of the entire country, in Romania, proposed the same thing. The main river in Bucharest (all the garbage goes into it) is dirty. Ceauşescu wanted to build beneath the river, which goes through the city, another river as a channel, so that 
underneath there would be all the dirt, and the upper level would be clean for people to enjoy. This was a kind of Fritzl architecture for the entire country. We have a long tradition of this purely architectural disposition. What about Fritz Lang's Metropolis? This for me is a nice example of how something Freud was describing has literally appeared. It's too easy to dismiss this as Austrian. It is also too easy to just say paternal authority as such. The thing to do would have been to ask what would have been the Fritzl phenomenon in each country. Each country has its own Fritzl. For example, the American Fritzl might be seen in ... a literary figure. The idea of the early big, brutal capitalists from the nineteenth century was that they raped their daughters. Remember, for example, Fitzgerald's Tender is the Night. Even Henry James's The Golden Bowl can be implicitly read this way. So the point is to look at equivalents of Fritzl.

A feminist journalist friend of mine made the following criticism of me. She said, 'OK, I agree with you about the decline of paternal authority, but you don't provide a positive alternative; all you provide is a negative vision, some kind of perverted narcissistic personality, we are go-getting, half-psychotic and so on'. But, she claimed, am I not aware that in Italy and some European countries the paternal decline is counteracted, supplemented, by the new role of the mother? This has nothing to do with the old patriarchal figure of the mother but is a totally new role of the mother, who holds together, not the family, but the unit with children. She even used the term 'Name of the Mother', claiming that a new entity is emerging. Now my point is that this is nice if it is true, but - to avoid misunderstanding, she is not a Luce Irigarary follower - my impression was that unfortunately, nice as such corroborating texts are (and they are undoubtedly true and I totally support such phenomena), this was just a kind of educational description of a phenomenon, of mother takes care of children. It doesn't answer the same question.

For Freud 'father' is not only the father who takes care of the family. It has a very precise structural place in how subjectivity is constituted. What I resist is some conservative leftists, especially in France - Adorno is close to this - who nonetheless think there was a good thing about traditional family that gets lost in today's cheap commercial society. They implicitly claim - there is, underlying the mainstream Frankfurt School, a very strong antifeminist tendency - that the totalitarian family is either feminine or homosexual. There are some very embarrassing remarks, incidentally, by Adorno here. I do buy the idea that the decline of paternal law means superego fear, but I don't agree that this superego is a feminine superego. It is a very fashionable idea in conservative leftists, the best known example is Christopher Lasch's The Culture of Narcissism. They try to put the blame on the woman.

\section{Freud and Social Change}

MA: All right, so if women will not make up for the lack in paternal authority, which you associate with the superego injunction to enjoy, then how 
does psychoanalysis help? You say that psychoanalysis is the only discourse that allows us not to enjoy, the only space where we don't have a duty to be happy. So how do you see psychoanalysis as rescuing us from the impasse of modernity?

Š̌: This is a very complex question. I try to be absolutely honest. I try not to promise what I cannot deliver. If beneath what you are asking me now is the big question, where does Freud really stand with regard to politics, I think the answer is pretty clear if you really look. I think Freud's position was, to put it very simply, that psychoanalysis allows us, when you analyse a society, to formulate, to articulate Unbehagen in der Kultur literally, the uneasiness in culture, but more famously translated as Civilization and Its Discontents. It does this basic symptomal job of showing how the failures, the pathological malfunctions, are symptomatic of the whole. I think that, for a true Freudian, it is totally wrong to distinguish the proper domain where you can use psychoanalysis. For the true Freudian it is not that Freud did his true job in his clinical analysis but then got a little bit crazy when he was writing Totem and Taboo and Unbehagen in der Kultur. No, because the whole point of Unbehagen in der Kultur is that these pathological phenomena are conditioned by the truth. They are the symptom, the result of what is wrong in the entire social body as such. In this sense, the two sides are necessarily connected. What is totally alien to Freud is this purely clinical idea that there is the normal functioning of society, then somebody doesn't work, then the psychoanalyst would have been like the psychological mechanic, the repairman who will set me straight.

I think that Freud, to put it in fashionable terms, isolates a certain excess. He calls it death drive, a certain excess of destructability that is, as it were, undermining, destabilizing the social order, an excess that is ambiguous in the sense that it can be a source of constructive energy or it can be purely destructive. The idea is that Freud isolates this space of excess, which then, of course, opens up the space for possible change. I think Freud's basic answer would have been: psychoanalysis just does this elementary job of showing how there is a gap, a failure, a nonfunctioning excess in society. But then, about what to do, he leaves it open. We cannot jump from here directly to positive programs. This then opens up all possible versions. You can have a conservative Freudian answer: the whole point is to control this threat. You can have a Reichian, naïve, Leftist answer: what is a threat is only a threat from the ruling perspective and we should identify ourselves with it. And you can have a liberal, middle-of-the-way game.

SF: The distinction you just made parallels a very old distinction that conservative theorists like Philip Reiff made ... the idea that psychoanalysis remains true as long as it restricts itself to the analysis of individual and social issues. But as soon as you start to fill that gap you get into a kind of ecstatic state - Reiff references Reich on this - in which you are promoting certain kinds of solutions that always turn out to be ... 
SŽ: Now we are coming to my point ... What I was saying is that I don't accept this conclusion.

SF: What positivity would you put in there? As you move past the stage of using psychoanalysis to analyze ailments and instead use it to prescribe cures, what would you put in there?

SŽ: I think the only consequent Freudian answer must be radical social change. Freud points in this way. It is crucial that Freud was very well aware of the proper dialectic tension between theory and practice. In what sense? In the sense that psychoanalytic theory is not only a theory of practice, but a theory of why the practice ultimately fails, has to fail. Or, as Freud put it, 'The only society in which psychoanalysis would have been really possible, as successful, is a society which wouldn't need psychoanalysis'. So the theory is not only a theory of practice, it is also a theory of why practice ultimately fails, and this theory is of Unbehagen in der Kultur.

If there is a conclusion from Freud, it is that of a move towards the social domain. Now, it is all open as to what to do at this level. But clearly the problem is there for Freud. Freud, I think, was a little like Lacan: uncertain, jumping here and there. For example, between 1905 and 1915 Freud had a certain 'sexual liberation' where he thought we just need to give more freedom and so on. My favourite Freud is - it is very uncanny - in his letter to Einstein where Freud - I love him there proposed a very weird formula (which people are almost embarrassed to refer to today) about the 'brutal dictatorship of reason'. My point is that I don't think you would get an entire social programme from psychoanalysis. What you can get is just this indication of how the key to the problem is social/symbolic global organization itself, so that change has to be at that level.

\section{The Position and Role of the Psychoanalytic Critic}

MA: You talk about language as torture, and yet you never stop talking. It's like you have this undead drive to keep talking. Despite the fact that not everything can be said, you keep adding more and more words, as if adding more signifiers might enable you to say everything. At the same time, in your published work you seek answers for what to do with one's symptom. On one hand, you enjoin us to enjoy our symptom, but you also say that for a true hero the real ethical task is to renounce that kernel of enjoyment, to renounce the symptom. So, should we renounce our symptom and traverse it, or should we hang on to it and enjoy it?

SŽ: First, I don't find any difficulty combining this, my incessant drive to speak, to this idea of torture in language. We struggle with language. All the great writers do this. Can we imagine - I don't like him - a greater torture of language than Joyce's Finnegan's Wake? As to the final question, this is again a 
very difficult problem. Already in Freud, in Lacan, it is interesting how you find totally different answers. Is it traversing the fantasy? Is it that you identify with the symptom, and so on and so on? All these formulas are for me basically problematic. More and more if you ask me - I am maybe under the influence of Badiou, I am doing something that will alienate me from some Lacanians - I am convinced that I am asking the wrong question here in the sense that what if this ultimate dimension of authenticity, to put it very naively, cannot be formulated? Maybe it is wrong to look at it from the level of psychoanalysis. Until recently, the ultimate horizon for me was that of traversing the fantasy. The question was, can we do it in politics? Jacques-Alain Miller implies - here I disagree with him, for Miller is now openly turning into a liberal, a kind of sceptical, ironic liberal - that politics ... the public domain, collective domain, is the domain of imaginary, symbolic identifications, illusions and so on. It is the domain of a lie. Being authentic can occur only when you focus on your singularity, break with it, and so on. So that all you can do, then, is ... you return to social life, but knowing that it's only an illusory game. That's what I try to avoid.

MA: I wonder if you would accept this as a description of what you have been doing: to begin with there was an emphasis on how to enjoy our hysteria, our neuroses, but now more and more in your recent books you enjoin us to be heroes. The notion of the hero that you and Badiou seem to return to is not one that psychoanalysis is very familiar with. In your In Defence of Lost Causes you even speak of heroic acts.

Š̌: People who criticize me for this 'heroic act', perhaps Yannis Stavrakakis, have noticed something strange, an interesting observation. They are right. All the acts I really refer to as acts are not what you would have expected. For example, from cinema, remember Atom Egoyan's The Sweet Hereafter, in which the girl who lies does so to sabotage, to win her case. They are very strange acts. My act is from Toni Morrison's Beloved: a mother killing her children; a girl telling a lie. Not exactly heroic acts. What I am saying - I claim that Lacan, towards the end, was approaching this when he struggled with the problems of political organization - is that when we have community, collective, what I call public space, a certain collectivity is established. To put it in very simplistic, Lacanian terms, the field is not organized through a master-signifier, we just relate directly to object $a$, object $a$ as the cause. I naively believe there are, in things like theoretical communities today-other collectives, where I do get some kind of authentic collectivity. This is my wager.

I think Lacan was struggling with this. He ridiculously failed, of course, but the struggle was the right one. You know all this: ridiculous rules, the Leninist topic of how to organize a psychoanalytic society, and the like. This was his late Leninist obsession: how to build a collective that would not be based on a lie, on primordial crime and all that Freudian stuff. This is what interests me, the idea of a religious collective as a collective that, paradoxically, doesn't need this big 
Other. I think the only thing I can tell you is that these things happen, you do get collectives like that.

SF: I found myself today wishing I were sitting behind you, to be the absent interlocutor in a way, the one who listens. We are used to thinking about the teacher as the one who attracts transferences and hence has the place of the analyst. But, in fact, like Lacan and like the way you speak, what happens to the speaker, the intellectual, is that he speaks and has no idea what response he is going to get from the audience. So, from a structural point of view, the speaker is in the position of a patient, who speaks and doesn't know how what he says is going to be heard. A simple question: what is the role of the intellectual if all the intellectual can do is speak and not know how he or she is going to be heard?

SZ: If there were a difference that we have to accept from this classical Marxist tradition of organic intellectuals, it is this: you are throwing bottles with messages into the sea and you don't know who, if anyone, will read them. We theoreticians today have to accept this.

SF: If there were an analyst there, what should his or her response be?

SŽ: That's a nice question. I think that ... there should be someone taking this role of the analyst. That's why I like your question. Lacan himself defined his own position in his Seminars, not writings, like this: it is not that he is analysing the public; the public is his audience, his big Other, and he literally improvises there. That is maybe the key to Lacan's inconsistency, that it really is almost the analysand's, the patient's, improvisations, with all the paradoxes that go with psychoanalysis. Freud describes how, when you retell your dream and at the end you add there's just another detail, which is probably not important, that's the crucial part. It is literally true of Lacan. If you look at what he says about repetition in Seminar XI, it's blah-blah, OK it's good; but then, in the first chapter of the next section of Seminar XI, the section on the gaze as object $a$, it is only there that he gives the formula of repetition.

With Freud it is often the same. The best part for me, the key to the entire Traumdeutung (Interpretation of Dreams) is one footnote towards the end of the chapter on the work of dreams, where he proposes the famous, almost Marxist, distinction that the crucial dimension of dreams is the form itself, not the content. This is why, for Lacan, hysteria is not a dismissive term. Hysterical discourse is the only productive one. New truth emerges there. It's great to be an analyst, but the analyst is the stupid guy; analysis is basically what Lacan was doing. What Lacan was doing - it's not a joke, I spoke with patients of Lacan who experienced this three main activities of Lacan during analysis were having cakes and tea, counting money, and interrupting with stupid questions. So the analyst is not productive. The analyst is a purely formal function; all the productivity, all the truth is with the hysteric. Hysteria is the place where something new emerges. 
MA: Hysterics are hysterical about the truth, and we are some of the people who are able to resist ideological interpellation.

SŽ: I have a problem here. I am for obsessional neurotics! Hysterics provoke, master commands, analyst sits down and does nothing, we obsessionals do all the work!

\section{Questions from the Floor}

\section{Political implications of Lacan's Seminar VII (The ethics of psychoanalysis)}

Derek Hook: Seminar VII, is this the seminar where we see the best and worst of Lacan? Towards the second half of the seminar there seems to be a kind of political resignation, a fatalism of needing to accept one's position.

SŽ: I totally agree with you because it is masked as radicality, and you know in what sense? It is a celebration of Antigone breaking out. It's even true (maybe you know it; it's a nice pathetic detail) that, while Lacan was doing this seminar, the daughter of his wife and Georges Bataille was in prison for aiding the Algerian independence struggle. He was bringing her drafts of his seminar that he was delivering - OK, let's leave aside the problem how this is arrogant, narcissistic of him. The point is that his fixation with Antigone had a certain radical political dimension to it. Which is why, incidentally, Yannis Stavrakakis, in his book The Lacanian Left- with all my respect for him, I don't think he is right - when he reads Antigone, to cut a long story short, as politically useless, a totally private suicidal gesture and so on. Stavrakakis mentions, as an even more crazy example, Oedipus at Colonus. My God, all the final part is pure politics, how he will sell his death, his body as a political founding act. So I find this very strange, how he can read Antigone and Oedipus at Colonus as some kind of private suicidal, self-obliteration and so on.

So I totally agree with you about Seminar VII . Beneath this mask of flirting with radicality it is basically this conservative vision, you know, we have these moments of self-obliterating encounters with truth, but then we return to normal life, servicing the good, and so on, and this vision, which is also today's predominant reactionary vision of May ' 68 ...

Stephen Frosh: But that's also the seminar with das Ding, which you use so much.

Slavoj Žižek: I think the danger with this seminar is two things. First, it is still at the level of this transgressive passion of the Real. I think that this is the seminar that is closest to Bataille. No wonder there are so many parallels between this seminar and Bataille. I don't think this is Lacan's last word. There is a hint in this direction. We all quote, even me, as Lacan's motto 'Do not compromise with regard to your desire'. Jean-Claude Milner made a nice 
observation here: everyone refers to this formula, but people forget that whenever Lacan uses certain formulas they are usually part of his doxa; he returns to them, reinterpreting them. But it is only one or two times in the last chapter that he mentions this 'Do not compromise your desire'; he never returns to it. And the reason is because it is not the true formula; he dropped it, basically. I think that it is absolutely crucial to read Antigone together with the next seminar, Seminar VIII, Transference, where you get Sygne de Coûfontaine, Claudel's character in his Coûfontaine-trilogy. Alenka Zupančič developed it already nicely in her Kant with Lacan book. Antigone is still a hero, there is narcissistic pleasure in self-sacrifice, there is a glorious spectacle, and so on. Alenka Zupančič focuses on this, how the moment she enters this domain, Atè, between the two deaths, she is an aesthetic object. You cannot say this for Sygne de Coûfontaine; it is a much more radical, tragical position.

The whole point of the last chapter of Seminar VII is to define an ethics of desire, which would have been an ethics of pure desire for Lacan, Antigone's le désir pur (pure desire). I think it is absolutely clear that, in the final chapter of Seminar XI, when Lacan emphasizes 'Le désir de l'analyste n'est pas le désire. [The desire of the analyst is not the pure desire]', the target is himself, earlier. I think it is a totally impossible position, the position of pure desire, where, as it were, the symbolic falls into the real, a kind of radical desire of a pure signifier.

\section{A 'Law of the Mother'?}

Lisa Baraitser: The issue about the 'law of the mother' ... I agree that it is probably pretty hopeless to build a law of the mother based on maternal practice compared to paternal practice and what people actually do with their children. If there was a way to articulate theoretically, in an adequate sense, a law of the mother, does it matter anymore, might there be a difference between maternal and paternal law ...?

SŽ: That's a good question. My reproach is not that women cannot be the law ... Paternal law for Lacan is not just that father has the authority. It involves a very specific inter-relation of desires, of prohibitions and so on. I would just like to get a precise description of how this would function in the mother's case. Is it basically the same structure that mother takes over, or is it different? How does identification work here - identification in the sense of the formation of the subject? The trick is that we silently presuppose what we are trying to prove. What do I mean by this? I will give you an example: Judith Butler. You remember that she claims that sexual difference is constructed, but, wait a minute, in what I think is her best book, The Psychic Life of Power, she has this theory that the primordial object of passionate attachment is of the same sex. She literally applies the Freudian lesson that identification is identification with a lost object, in the sense that you become your lost object, you become what you have to renounce. Ok, so, in other words, you become a 
woman by abandoning the woman as object and so on. Of course, her idea is that homosexuals retain a fidelity, a melancholic fidelity. OK, no problem. The problem is that if, according to her - and I asked her this once and didn't get a clear answer - if sexual difference is later constructed, then how is it that you can choose the same sex? If you choose the same sex, then at that level you must already have some experience of the different sexes. It's a little bit too circular for me.

\section{About the Authors}

Slavoj Žižek (interviewee) is a Slovenian Marxist philosopher and cultural critic who is the author of over forty books and the subject of two major films: The Pervert's Guide to Cinema and Žižek! He is currently the international director of the Centre for Advanced Studies in the Humanities at Birkbeck College at the University of London.

Maria Aristodemou (interviewer) is a senior lecturer in Law at Birkbeck College, London.

Stephen Frosh (interviewer) is a Professor of Psychology and Pro-Vice-Master, Department of Psychosocial Studies, School of Social Sciences, History and Philosophy, Birkbeck College, London.

Derek Hook (transcriber and editor) is a lecturer in Social Psychology at The London School of Economics and a visiting associate professor in psychology at the University of the Witwatersand. 